\title{
MAKALAH \\ PERMASALAHAN KEBIJAKAN PELAYANAN TERPADU SATU PINTU (PTSP) DAN SOLUSINYA
}

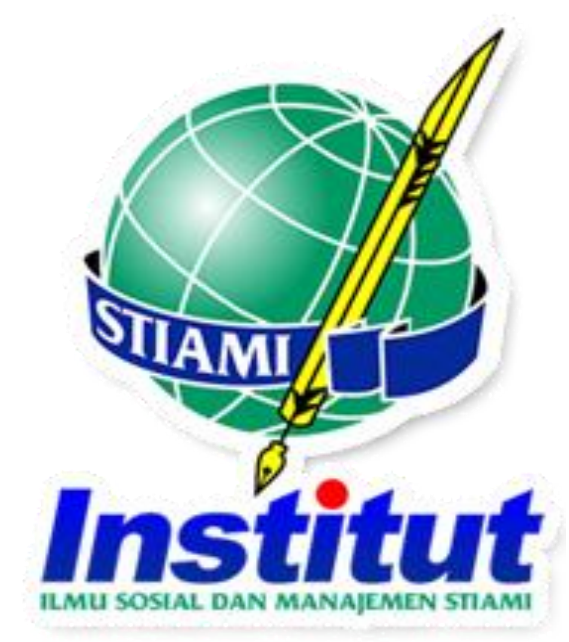

Disusun oleh :

MARTHA ANGELICA (BC191110047)

MOMPO SONTYARA SIRAIT (BC191110064)

MUHAMAD SAFEI (BC191120014)

Dosen : Dr. Ir. A.H Rahardian, M.Si

TEORI ADMINISTRASI PUBLIK KONTEMPORER

MAGISTER ADMINISTRASI PUBLIK

INSTITUT ILMU SOSIAL DAN MANAJEMEN STIAMI

2019 


\section{KATA PENGANTAR}

Puji dan syukur kami panjatkan ke hadirat Tuhan yang maha kuasa, yang telahmemberikan izin dan kekuatan kepada kami, sehingga kami dapat menyelesaikan makalah ini dengan judul "PERMASALAHAN KEBIJAKAN PELAYANAN TERPADU SATU PINTU (PTSP) DAN SOLUSINYA" tepat pada waktunya.

Tugas ini ditujukan untuk memenuhi tugas mata kuliah Teori Administrasi Publik Lanjutan.Dan juga kami mengucapkan terimakasih kepada:

1. Bapak Dr. Ir. A. H. Rahardian M.Si selaku dosen pembimbing mata kuliah Teori Administrasi Publik Lanjutan

2. Semua pihak yang tidak sempat kami sebutkan satu per satu yang turut membantu kelancaran dalam penyusunan makalah ini.

Kami menyadari bahwa makalah ini masih banyak kekurangan dan kelemahannya baik dalam isi maupun sistematikanya. Hal ini disebabkan oleh keterbatasan pengetahuan dan wawasan kami. Oleh sebab itu, kami sangat mengharapkan kritik dan saran untuk menyempurnakan makalah ini.

Akhirnya kami mengharapkan semoga makalah ini dapat memberikan manfaat khususnya bagi kami dan umumnya bagi pembaca.

Jakarta, 18 oktober 2019

Penyusun

Kelompok VII 


\section{DAFTAR ISI}

Halaman

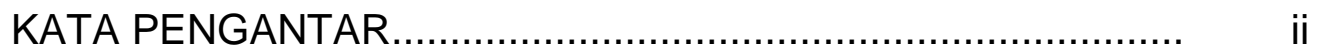

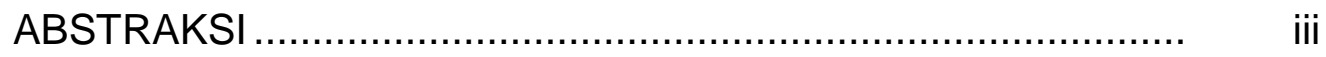

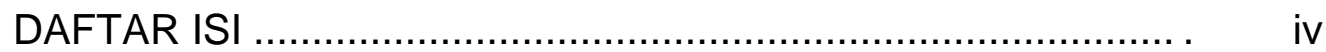

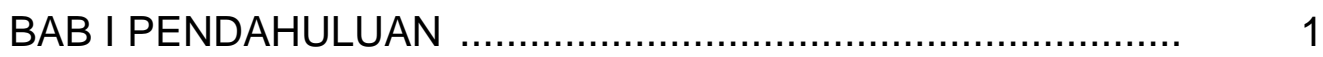

A. Latar Belakang Masalah ........................................ 1

B. Ruang Lingkup Penulisan.................................. 5

C. Tujuan dan Manfaat Penulisan ..................................... 6

BAB II PERMASALAHAN ............................................. 8

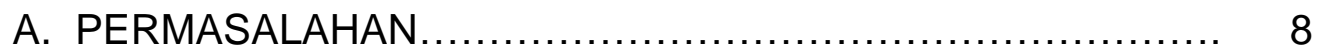

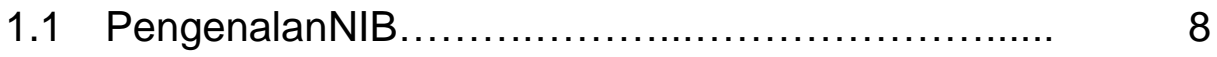

1.2 Permasalahan................................. 9

BAB III SOLUSI (PEMECAHAN MASALAH) ....................... 11

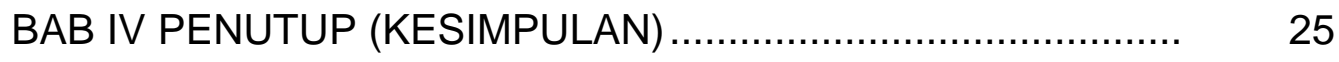

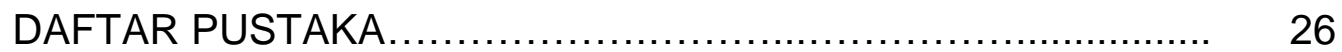




\section{ABSTRACTION}

The Online Single Submission System (OSS) was built in the context of accelerating and increasing investment and business, by implementing an integrated electronic business licensing. In the latest regulation regarding Online Single Submission (OSS), namely PP No. 24 of 2018, the Government regulates among other things the types, applicants, and issuance of business permits; implementation of business licensing; business licensing reforms per sector, OSS system, Online Single Submission (OSS), Online Single Submission (OSS) funding; incentives or disincentives for business licensing through OSS; problem solving and business obstacles; and sanctions.

The OSS system reverses the previous licensing process. If previously an operational permit or commercial permit was issued after a series of permits such as an environmental permit, AMDAL, etc., was pocketed by the entrepreneur. However, with OSS, with a Business Identification Number (NIB), entrepreneurs can obtain operational licenses and commercial permits, and the AMDAL process is completed in stages after the NIB is published.

The regulation assumes that in order to speed things up the procedure is summarized, which is wrong. The government should prioritize disclosure of public information related to AMDAL, or strengthen the AMDAL assessment team which unfortunately was not touched by PP OSS. Therefore, he considered that the government misidentified the problem at this stage.

The presence of PP OSS actually makes the AMDAL position not strategic when only by pocketing commitment licenses, businesses can get environmental permits. With an environmental permit, businesses can carry out various activities such as land acquisition and so on. So that the existence of an AMDAL does not affect anything to the project except mitigation related impacts that must be addressed. (Environmental and Forestry Experts, Hariadi Kartodiharjo)

Keyword: SOSIALISASI, NIB and AMDAL 


\section{BAB I}

\section{PENDAHULUAN}

\section{A. LATAR BELAKANG MASALAH}

Peran utama pemerintah terhadap rakyatnya adalah memberikan pelayanan dalam rangka memenuhi kebutuhan yang diinginkan oleh masyarakat. Peranan pemerintah mengalami perubahan sesuai dengan tuntutan dan dinamika masyarakat yang berkembang. Walaupun peran pemerintah mengalami berbagai perubahan namun pada pokoknya tugas pemerintah adalah memberikan pelayanan yang terbaik kepada masyarakat. Tugas pelayanan pemerintah sangat relevan dengan pencapaian tujuan nasional sebagaimana tercantum dalam alinea keempat Pembukaan UUD 1945:

1. Melindungi segenap bangsa Indonesia dan tumpah darah Indonesia;

2. Memajukan kesejateraan umum;

3. Mencerdaskan kehidupan bangsa;

4. Ikut melaksanakan ketertiban dunia yang berdasarkan kemerdekaan, perdamaian abadi dan keadilan sosial.

Dewasa ini penyelenggaraan pelayanan publik masih dihadapkan pada kondisi yang belum sesuai dengan kebutuhan dan perubahan di berbagai bidang kehidupan bermasyarakat, berbangsa, dan bernegara. Hal tersebut bisa disebabkan oleh ketidaksiapan untuk menanggapi terjadinya transformasi nilai yang berdimensi luas serta dampak berbagai masalah pembangunan yang kompleks. Sementara itu, tatanan baru masyarakat Indonesia dihadapkan pada harapan dan tantangan global yang dipicu oleh kemajuan dibidang ilmu pengetahuan, informasi, komunikasi, transportasi, investasi, dan perdagangan 
Perkembangan dan kemajuan otonomi daerah terus digalakan hingga terwujudnya Otonomi daerah yang diharapkan yakni otonomi daerah yang mandiri. Pelaksanaan otonomi daerah mendorong pemikiran baru bagaimana menata kewenangan yang efektif dan efisien. Artinya pemerintah dapat diselenggarakan secara demokratis, dan dapat memberikan kemudahan bagi masyarakat.

Kondisi dan perubahan cepat yang diikuti pergeseran nilai tersebut perlu disikapi secara bijak melalui langkah kegiatan yang terus-menerus dan berkesinambungan dalam berbagai aspek pembangunan untuk membangun kepercayaan masyarakat guna mewujudkan tujuan pembangunan nasional

Daerah memiliki kewenangan membuat kebijakan daerah untuk memberi pelayanan, peningkatan peran serta dan pemberdayaan masyarakat yang bertujuan untuk meningkatkan kesejahteraan rakyat. Sejalan dengan hal tersebut, maka dilaksanakan pula prinsip otonomi daerah yang nyata dan bertanggung jawab. Prinsip yang nyata adalah prinsip yang menegaskan bahwa urusan pemerintahan didasarkan berdasarkan tugas, wewenang dan tanggung jawab. (waluyo, 2007:206)

Penyelanggaraan pemerintahan saat ini bukan lagi semata-mata menjadi tanggung jawab pemerintah, melainkan seluruh aktor dalam sebuah Negara. Meskipun demikian, peran pemerintah tentunya masih sangat dibutuhkan terkait dengan penyediaan pelayanan publik. Pelayanan publik mencangkup tiga aspek yaitu, pelananan barang, jasa, dan administratif. Di dalam Pelayanan Publik yang mencangkup tiga aspek tersebut sangatlah penting dalam aspek pemerintahan supaya efektif dan efisien.

Pelayanan merupakan wujud dari fungsi pemerintahan sebagai bukti pengabdian kepada masyarakat. Rendahnya kualitas di Indonesia saat ini mendorong pemerintah untuk segera memperbaiki kualitas pelayanannya, apalagi yang berhubungan dengan pelayanan perizinan yang dicitrakan sebagai pelayanan 
yang berbelit-belit, sulit diakses, memiliki prosedur yang sangat rumit serta tidak adanya kepastian waktu dan keterbukaan biaya pelayanan yang dibutuhkan.

Atas dasar itulah, Pemerintah Indonesia mengistrusikan kepada seluruh kepala daerah agar dapat segera menerapkan pola pelayanan perizinan terpadu satu pintu melalui Peraturan Menteri Dalam Negeri Nomor 24 Tahun 2006 tentang Pedoman Penyelenggaraan Perizinan Terpadu Satu Pintu, yang jenis kelembagaannya diserahkan kepada daerah jenis lembaga yang sesuai dan disesuaikan dengan kemampuan dan kebutuhan daerah dalam mengelola, dengan dibentuknya Pelayanan Perizinan Terpadu Satu Pintu.

Penyelenggaraan Pelayanan Terpadu Satu Pintu adalah Kegiatan penyelenggaraan perizinan dan non perizinan yang proses pengelolaannya mulai dari tahap permohonan sampai ke tahap terbitnya dokumen dilakukan di satu tempat. Dalam hal Pelayanan Terpadu Satu Pintu, kepala PTSP diberi pelimpahan kewenangan untuk menandatangani izin yang masuk, ini berarti penyederhanaan pelayanan. Penyederhanaan pelayananan adalah upaya peningkatan terhadap waktu, prosedur, dan biaya pemberian perizinan dan non perizinan.

Perizinan adalah pemberian legalitas kepada seseorang atau pelaku usaha/kegiatan tertentu, baik dalam bentuk Izin maupun Tanda Daftar Usaha. Pemberlakuan Pelayanan Terpadu Satu Pintu (PTSP) ini diharapkan mampu memangkas waktu dan biaya yang dibutuhkan untuk mengurus perizinan hasilnya memberikan pelayanan perizinan yang lebih efektif, mudah dan murah (Peraturan Menteri dalam Negeri Nomor 24 Tahun 2006 tentang Pedoman Penyelenggaraan Perizinan Terpadu Satu Pintu).

Efektivitas dapat diartikan sebagai tepat sasaran yang juga lebih diarahkan pada aspek keberhasilan pencapaian tujuan. Maka efektivitas fokus pada tingkat pencapaian terhadap tujuan dari organisasi publik. Dalam kaitannya terhadap pelayanan perizinan, pemerintah berusaha menciptakan suatu system pelayanan yang optimal. Salah satu dari tindakan pemerintah tersebut adalah dengan dikeluarkannya suatu kebijakan Pelayanan Terpadu Satu Pintu atau (PTSP). 
Demikian pentingnya pelayanaan publik yang diberikan pemerintah kepada masyarakat, sehingga sering dijadikan indikator keberhasilan suatu pemerintahan. Apalagi dalam rangka mewujudkan good governance dimana akuntabilitas menjadi salah satu prinsip yang harus di kedepankan dalam penyelenggaraan pemerintah sektor publik menjadi suatu keharusan yang tidak bisa di tunda-tunda, untuk menjamin kebutuhan masyarakat dalam pelayanan publik yang efektif dan efesien.

Pemerintah terus berupaya untuk mempermudah proses perizinan di Indonesia. Hadirnya Online Single Submission (OSS) yang diluncurkan pada tahun lalu diharapkan dapat mendukung upaya percepatan penanaman modal. OSS merupakan platform yang disediakan pemerintah untuk mengurus perizinan secara terintegrasi.

Layanan Perizinan Berusaha Terintegrasi Secara Elektronik (PBTSE), yang lebih mudah disebut dengan nama generik OSS ini hadir dalam rangka pelayanan perizinan berusaha yang berlaku di semua Kementerian, Lembaga, dan Pemerintah Daerah di seluruh Indonesia yang selama ini dilakukan melalui Perizinan Terpadu Satu Pintu (PTSP). Selain melalui PTSP, masyarakat dapat mengakses Sistem OSS secara daring di mana pun dan kapan pun.

Sistem OSS dibangun dalam rangka percepatan dan peningkatan penanaman modal dan berusaha, dengan menerapkan perizinan berusaha terintegrasi secara elektronik. Dalam beleid terbaru mengenai OSS, yakni Peraturan Pemerintah Nomor 24 Tahun 2018 tentang Pelayanan Perizinan Berusaha Terintegrasi Secara Elektronik, Pemerintah mengatur antara lain tentang jenis, pemohon, dan penerbitan perizinan berusaha; pelaksanaan perizinan berusaha; reformasi perizinan berusaha per sektor, sistem OSS, lembaga OSS, pendanaan OSS; insentif atau disinsentif pelaksanaan perizinan berusaha melalui OSS; penyelesaian permasalahan dan hambatan brusaha; serta sanksi. 
Pelayanan Terpadu Satu Pintu salah satunya adalah NIB atau Nomor Induk Berusaha, yang dimana semua Perizinan tidak dipisahkan tetapi digabung menjadi satu untuk itu penulis mengambil judul makalah "Permasalahan Kebijakan Pelayanan Terpadu Satu Pintu (PTSP) dan Solusinya". Dengan mengambil studi kasus yang akan kami teliti yaitu NIB atau Nomor Induk Berusaha.

\section{B. Ruang Lingkup Penulisan}

Dalam penulisan makalah ini dilakukan untuk adanya Permasalahan dalam PTSP di dalam pengaplikasian terhadap masyarakat dalam kebijakan publik terkait satu pintu. Penulis ingin megetahui permasalahan dan bagaimana solusi dari PTSP dalam NIB, dan pengetahuan masyarakat dengan penggunaan NIB untuk kepuasan masyarakat agar kebijakan publik dalam PTSP ini bisa berfungsi secara efektif dan efisien, indikator-indikatornya sebagai berikut:

1. Pelayanan Prima

a. Kesederhanaan, indikator: prosedur tidak berbelit-belit, mudah dipahami dan mudah dilaksanakan.

b. Kejelasan, indikator: persyaratan teknis dan administrasi.

c. Kepastian Waktu, indikator: pelaksanaan pelayanan diselesaikan dalam kurun waktu yang telah ditentukan.

d. Akuransi, indikator: produk pelayanan diterima dengan benar, tepat dan sah.

e. Keamanan, indikator: proses pelayanan memberikan rasa aman dan kepastian hokum.

f. Tanggungjawab, indikator: pejabat pelayanan bertanggung jawab atas penyelanggaraan pelayanan dan penyelesaian keluhan.

g. Kelengkapan sarana dan prasarana, indikator: tersedianya sarana dan prasarana kerja.

h. Kemudahan akses, indikator: tempat dan lokasi serta sarana pelayanan yang memadai dan mudah dijangkau.

i. Kedisiplinan, Kesopanan, dan Keramahan, indikator: petugas pelayanan bersikap disiplin, sopan, santun, ramah serta memberikan pelayanan dengan ikhlas. 
j. Kenyamanan, indikator: ruang tugas yang nyaman, bersih, rapi.

2. Kepuasan Pelanggan

a. Bukti langsung (Tangibles), indikatornya: fasilitas fisik, perlengkapan, pegawai dan sarana komunikasi.

b. Kendala (Reliability), indikatornya: petugas pelayanan bersikap empati dan komitment terhadap waktu layanan.

c. Daya Tanggap (Responsiveness), indikatornya: membantu para pelanggan dan memberikan pelayanan dengan cepat tanggap.

d. Jaminan (Empathy), indikatornya: komunikasi yang baik, perhatian, dan memahami kebutuhan pelanggan.

\section{TUJUAN DAN MANFAAT PENULISAN}

Adapun tujuan dari Makalah penulisan ini adalah:

1. Untuk mengetahui adanya kendala dan solusi untuk pelayanan prima terhadap kepuasan pelanggan di Unit Pelayanan Satu Pintu (PTSP) pada sistem OSS yaitu NIB.

2. Sebagai salah satu bentuk penilaian makalah matakuliah Adminisrtrasi Publik Kontemporer, untuk tugas Kelompok.

Sedangkan manfaat yang ingin dicapai dengan diadakan penelitian ini adalah sebagai berikut :

1. Bagi Penulis

Untuk menambah pengetahuan serta memperluas wawasan penulis mengenai pelayanan prima dan kepuasan pelanggan untuk Pelayanan Terpadu Satu Pintu dengan NIB secara satu pintu dan secara online.

2. Bagi pembaca

Sebagai bahan referensi dan informasi untuk pembaca yang ingin melakukan penelitian lebih lanjut, terutama yang berhubungan dengan kepuasan cara mengatasi kendala dan solusi untuk PTSP dalam satu pintu dengan salah satunya NIB (Nomor Induk Berusaha). 


\section{BAB II}

\section{PERMASALAHAN}

\subsection{PENGENALAN NOMOR INDUK BERUSAHA (NIB)}

Sistem OSS dibangun dalam rangka percepatan dan peningkatan penanaman modal dan berusaha, dengan cara menerapkan perizinan berusaha terintegrasi secara elektronik. Dalam beleid terbaru mengenai OSS, yakni PP No. 24 Tahun 2018, Pemerintah mengatur antara lain tentang jenis, pemohon, dan penerbitan perizinan berusaha; pelaksanaan perizinan berusaha; reformasi perizinan berusaha per sektor, sistem OSS, lembaga OSS, pendanaan OSS; insentif atau disinsentif pelaksanaan perizinan berusaha melalui OSS; penyelesaian permasalahan dan hambatan brusaha; serta sanksi.

Sistem OSS membalik proses perizinan yang dilakukan sebelumnya. Jika sebelumya izin operasional atau izin komersil dikeluarkan setelah serangkaian perizinan seperti izin lingkungan, AMDAL, dan lain sebagainya, dikantongi oleh pengusaha. Namun dengan OSS, dengan Nomor Induk Berusaha (NIB), pengusaha bisa mendapatkan izin operasional dan izin komersil, dan proses AMDAL diselesaikan secara bertahap pasca NIB terbit.

NIB adalah Nomor Induk Berusaha, di dalam Pedoman Perizinan Berusaha melalui OSS atau Online Single Submission. OSS adalah Perizinan Berusaha yang diterbitkan oleh lembaga dan atas nama menteri, pimpinan lembaga, gubernur, atau bupati/wali kota kepada Pelaku Usaha melalui system elektronik yang terintegrasi. Semua pelaku usaha dengan karakteristik sebagai berikut :

1. Berbentuk badan usaha maupun perorangan

2. Usaha mikro, kecil, menengah maupun besar

3. Usaha perorangan/badan usaha baik yang baru maupun yang sudah berdiri sebelum operasional OSS 
4. Usaha dengan modal yang seluruhnya berasal dari dalam negeri, maupun terdapat komposisi modal asing.

Manfaat menggunakan OSS bagi pelaku usaha

1. Mempermudah pengurusan berbagai perizinan berusaha baik persyaratan untuk melakukan (izin terkait lokasi, lingkungan, dan bangunan), izin usaha, maupun izin operasional untuk kegiatan operasional usaha di tingkat pusat ataupun daerah dengan mekanisme pemenuhan komitmen persyaratan izin.

2. Memfasilitasi pelaku usaha untuk terhubung dengan semua stakeholder dan memperoleh izin secara aman, cepat dan real time.

3. Memfasilitasi pelaku usaha dalam melakukan pelaporan dan pemecahan masalah perizinan dalam satu tempat

4. Memfasilitasi pelaku usaha untuk menyimpan data perizinan dalam satu identitas berusaha (NIB).

NIB sekaligus berlaku sebagai :

1. Tanda Daftar Perusahaan (TDP)

2. Angka Pengenal ImpoR (API), jika pelaku usaha akan melakukan kegiatan impor

3. Akses Kepabeanan, jika pelaku usaha akan melakukan kegiatan ekspor dan impor

NIB wajib dimiliki pelaku usaha yang ingin mengurus perizinan berusaha melalui OSS, baik usaha baru maupun usaha yang sudah beridiri sebelum oprasionalisasi OSS. Pelaku usaha dapat memperoleh dokumen pendaftaran lainnya yaitu :

1. NPWP Badan atau Perorangan, jika pelaku usaha belum memiliki.

2. Surat Pengesahan Rencana Penggunanaan Tenaga Kerja Asing (RPTKA)

3. Bukti Pendaftaran Kepersetaan BPJS Ketenagakertajaan dan BPJS Kesehatan.

4. Nontifikasi kelayakan untuk memperoleh fasilitas fiscal dan atau, 
5. Izin Usaha, misalnya untuk Izin Usaha di sektor Perdagangan (Surat Izin Usaha Perdagangan (SIUP)).

\subsection{PERMASALAHAN}

Sistem OSS memiliki beberapa permasalahan yang cukup menghambat proses pengurusan izin tersebut, berikut adalah beberapa contoh permasalahan dari system OSS pada NIB :

1. Kurangnya sosialisasi antara pihak pelayanan satu pintu kepada masyarakat.

2. Kurangnya pemberitahuan kepada masyarakat secara meluas atau seminar terkait Pelayanan Terpadu Satu Pintu, sehingga menyebakan ketidak merataan di dalam online sistem yang memudahkan masyarakat.

3. Pelayanan Terpadu Satu Pintu tidak memberitahukan kepada masyarakat secara meluas tentang perubahan - perubahan ketentuan PTSP NIB, Misal Domisi Perusahaan ikut bergabung didalam NIB dan tidak secara terpisah, hanya di wilayah DKI Jakarta, tetapi diluar wilayah DKI Jakarta banyak yang tidak mengetahui apakah domisili perusahaan tergabung dalam NIB atau tidak.

4. Banyaknya masyarakat yang mengeluh tentang kegagalan dalam membuat $\mathrm{NIB}$, tetapi tidak disebutkan adanya kekurangan dokumen apa yang harus dilengkapi untuk mendaftar PTSP online yaitu NIB.

5. Kurangnya pelayanan yang baik dalam contact center oss di 08071002576 dan tidak ada respon ketika mengirim email ke helpdesk untuk membuat list kasus melalui aplikasi namun semua nihil tidak ada respon untuk membantu.

6. proses AMDAL yang diletakkan setelah NIB terbit dapat melemahkan posisi AMDAL yang selama ini berfungsi sebagai pengambil keputusan 


\section{BAB III}

SOLUSI

\subsection{PEMECAHAN MASALAH}

Keluhan merupakan suatu wujud rasa ketidakpuasan konsumen. Keluhan berpengaruh besar bagi kemajuan perusahaan. Keluhan yang terselesaikan dengan baik dan profesional akan berdampak positif nantinya bagi perusahaan tersebut, karena dengan begitu pelanggan tersebut merasa sangat dihargai pendapatnya. Hal itu merupakan hak bagi para konsumen untuk menyampaikan rasa ketidakpuasannya.

Pada umumnya keluhan pelanggan datang dikarenakan oleh lemahnya penangan komunikasi, sehingga imformasi tidak dapat diterima secara maksimal dan banyak yang mungkin saja menjadi janggal di benak masyarakat selaku konsumen. Untuk itu, dibutuhkan team untuk menangani keluhan konsumen dengan pengetahuan yang cukup agar keluhan pelanggan dapat di kelola secara benar.

Keluhan merupakan sebuah pertanda adanya ketidakpuasan. Apabila hal tersebut tidak ditindaklanjuti, pelanggan akan pindah ke pemasok dan/atau merek produk atau jasa yang lain, berpartisipasi dalam word of mouth (WoM) negatif, atau melakukan keluhan ke organisasi/pihak ketiga (Lam \& Dale, 1999; Davidow, 2000). Akan tetapi yang paling berbahaya adalah, pelanggan tidak melakukan tindakan apapun kepada organisasi. Secara diam-diam mereka menghukum organisasi dengan cara "pindah" ke organisasi yang lain, organisasi yang mereka pandang akan memberikan kepuasan kepada mereka. Adanya perilaku "switching" secara diamdiam ini menyebabkan organisasi tidak memiliki kesempatan untuk mempertahankan pelanggannya. Organisasi tidak memiliki informasi apapun mengenai mengapa mereka tidak puas (Kotler, 2000) 
Adapun solusi yang dapat di selesaikan, adanya pelayanan publik yang excellent, kita harus mengetahui terlebih dahulu definisi administrasi, administrasi publik, pelayanan serta pelayanan publik, penulis mengambil dari beberapa referensi buku tentang arti pelayanan publik berserta yang baik agar berjalanya PTSP yang efektif dan efisien, berikut adalah teori yang penulis ambil untuk pelayanan publik yang seharusnya diberlakukan oleh intensi pemerintahan agar pelayanannya prima :

Pengertian Administrasi Publik

a. Pengertian

1) Administrasi

Sondang P. Siagian mendefinisikan administrasi sebagai "keseluruhan proses kerja sama antara dua orang manusia atau lebih yang didasarkan atas rasionalitas tertentu untuk mencapai tujuan yang telah ditetapkan sebelumnya. Sedangkan Dwight Waldo (1971) Administrasi ialah suatu bentuk daya upaya manusia yang kooperatif yang memiliki tingkat rationaliteit yang tinggi

2) Administrasi Publik

Menurut Nicholas Henry, Administrasi Publik adalah suatu kombinasi yang kompleks antara teori dan praktek, dengan tujuan mempromosikan pemahaman terhadap pemerintah dalam hubungannya dengan masyarakat yang diperintah, dan juga mendorong kebijakan publik agar lebih responsif terhadap kebutuhan sosial. Sementara Chandler dan Plano dalam Keban (2004:3), Administrasi Publik adalah proses dimana sumber daya dan personel publik diorganisir dan dikoordinasikan untuk memformulasikan, mengimplementasikan, dan mengelola keputusan-keputusan dalam kebijakan publik 
Dalam administrasi publik sendiri memiliki kajian yang dapat dipelajari, adapun Kajian administrasi publik yang dapat dipelajari adalah:

1. Kebijakan Publik

2. Manajemen Publik

3. Keuangan negara

4. Administrasi Pembangunan

5. Otonomi Daerah

6. Hubungan Eksekutif dan Legislatif

7. Etika Administrasi Publik

8. Pelayanan Publik

9. Manajemen Sumber Daya Manusia Sektor Publik

10. Good Governance dan Local Governance

Selain memiliki kajian yang dapat dipelajari, dalam administrasi publik juga memiliki fungsi yang dapat dijadikan acuan saat pelaksanaan kebijakan publik, adapun fungsi administrasi publik ialah sebagai berikut:

1. Planning (Perencanaan)

2. Organizing (Pengorganisasian)

3. Staffing

4. Directing (Pengarahan)

5. Coordinating

6. Reporting (Pelaporan)

7. Budgeting (penganggaran)

Bailey (dalam Darwin,1997) menjelaskan empat macam teori yang secara keseluruhan dapat memberikan kontribusi terhadap praktek administrasi negara, yaitu: 


\section{a. Teori Deskriptif Eksplanatif}

Teori deskriptif-eksplanatif memberikan penjelasan secara abstrak realitas administrasi negara baik dalam bentuk konsep, proposisi, atau hukum (dalil). Misalnya, konsep hirarki dari organisasi formal. Konsep ini menjelaskan ciri umum dari organisasi formal yaitu adanya penjenjangan dalam struktur organisasi.

Pada dasarnya teori deskriptif-eksplanatif menjawab dua pertanyaan dasar: apa dan mengapa (apa berhubungan dengan apa). Pertanyaan apa: menuntut jawaban deskriptif mengenai suatu realitas yang dijelaskan secara abstrak ke dalam suatu konsep tertentu. Misal: hirarki organisasi formal, konflik peran, dsb. Pertanyaan mengapa atau apa berhubungan dengan apa menuntut jawaban eksplanatif atau diagnostik mengenai keterkaitan antara konsep abstrak tertentu dengan konsep abstrak lainnya. Misalnya, konflik peranan berhubungan dengan tipe kegiatan apakah departemental atau koordinatif. Kegiatan yang dilaksanakan satu departemen kurang begitu menimbulkan konflik peran dibanding jika kegiatan dilaksanakan secara koordinatif.

b. Teori Normatif

Teori normatif bertujuan menjelaskan situasi administrasi masa mendatang secara prospektif. Termasuk dalam teori ini adalah pernyataan atau penjelasan-penjelasan yang bersifat utopia yaitu suatu cita-cita yang sangat idealistis.

Teori normatif juga dapat dikembangkan dengan merumuskan kriteria-kriteria normatif yang lebih spesifik seperti efisiensi, efektivitas, responsivitas, akutabilitas, demokrasi, dan sebagainya. Teori normatif memberikan rekomendasi ke arah mana suatu realitas harus dikembangkan atau perlu dirubah dengan menawarkan kriteria-kriteria normatif tertentu. 
Persoalan dalam teori normatif adalah bahwa kriteria-kriteria normatif yang ditawarkan tidak selalu mendukung bahkan bisa saling bertentangan. Misalnya, penekanan yang terlalu tinggi pada efisiensi dapat mengorbankan pemerataan (equity). Sentralisasi yang berlebihan dapat menghambat atau membunuh nilai-nilai demokrasi seperti partisipasi, akuntabilitas publik, transparansi dan pemberdayaan masyarakat.

Kriteria-kriteria normatif dalam teori administrasi seringkali terkesan ambisius. Kontradiktif dan relatif (dibatasi ruang dan waktu). Namun teori normatif tetaplah penting karena kemajuan administrasi negara akan lebih terarah bila terlebih dahulu ditentukan kriteria yang tepat untuk mengukur kemajuan tersebut.

c. Teori Asumtif

Teori asumtif menekankan pada prakondisi atau anggapan adanya suatu realitas sosial dibalik teori atau proposisi yang hendak dibangun. Menurut Bailey teori administrasi lemah dalam menyatakan asumsi-asumsi dasar tentang sifat manusia dan institusi. Tanpa asumsi yang jelas membuat teori menjadi utopis atau ahistoris karena tidak jelas dasar berpijaknya.

Contoh teori asumtif dalam administrasi publik adalah Teori $\mathrm{X}$ dan $Y$ dari Douglas McGregor. Teori ini mengemukakan sua jenis asumsi yang berlawanan tentang sifat manusia. Teori $X$ berasumsi bahwa pada dasarnya manusia malas dan suka menghindari pekerjaan, sedang teori $Y$ berasumsi bahwa manusia memiliki kemauan untuk bekerja dan memiliki kemampuan untuk mengemban tanggungjawab yang dibebankan kepadanya. Masingmasing asumsi ini mempunyai implikasi dalam pengembangan teori manajemen atau kepemimpinan dalam organisasi. 


\section{d. Teori Instrumental}

Pertanyaan pokok yang dijawab dalam teori ini adalah 'bagaimana' dan 'kapan'. Teori instrumental merupakan tindak lanjut dari proposisi "jika-karena". Misalnya: Jika sistem administrasi berlangsung secara begini dan begitu, karena ini dan itu atau jika desentralisasi dapat meningkatkan efektivitas birokrasi, maka strategi, tehnik, alat apa yang dikembangkan untuk menunjangnya.

Analisis kebijakan adalah contoh teori instrumentasl. Analisis kebijakan banyak menyumbangkan atau mengaplikasikan tehnik baik kuantitatif - aplikasi regresi, riset operasi, analisis biaya dan manfaat-maupun kualitatif (rasional maupun intuitif) untuk menjawab pertanyaan 'bagaimana' dan 'kapan' Jawaban terhadap pertanyaan ini berguna sebagai rekomendasi kepada pengambil kebijakan dalam menentukan langkah-langkah konkrit dalam proses kebijakan publik

1. Pengertian Pelayanan Publik

a. Pengertian

1) Pelayanan

Berkaitan dengan pelayanan, ada dua istilah yang perlu diketahui, yaitu melayani dan pelayanan. Pengertian melayani adalah "membantu menyiapkan (mengurus) apa yang diperlukan seseorang". Sedangkan pengertian pelayanan adalah "usaha melayani kebutuhan orang lain" (Kamus Besar Bahasa Indonesia, 1995). Pelayanan pada dasarnya adalah kegiatan yang ditawarkan oleh organisasi atau perorangan kepada konsumen (customer/yang dilayani), yang bersifat tidak berwujud dan tidak dapat dimiliki. Hal ini sesuai dengan apa yang 
disampaikan oleh Norman (1991:14) mengenai karakteristik tentang pelayanan, yakni sebagai berikut:

a) Pelayanan bersifat tidak dapat diraba, pelayanan sangat berlawanan sifatnya dengan barang jadi;

b) Pelayanan itu kenyataannya terdiri dari tindakan nyata dan merupakan pengaruh yang sifatnya adalah tindakan sosial;

c) Produksi dan konsumsi dari pelayanan tidak dapat dipisahkan secara nyata, karena pada umumnya kejadiannya bersamaan dan terjadi di tempat yang sama. Karakteristik di atas dapat menjadi dasar bagaimana memberikan pelayanan yang terbaik.

Pengertian yang lebih luas juga disampaikan oleh Daviddow dan Utal (1989:19) bahwa pelayanan merupakan usaha apa saja yang mempertinggi kepuasan pelanggan (whatever enhancescustomer satisfaction).

2) Pelayanan Publik

Dalam Undang-Undang Nomor 25 Tahun 2009 dinyatakan bahwa Pelayanan publik adalah kegiatan atau rangkaian kegiatan dalam rangka pemenuhan kebutuhan pelayanan sesuai dengan peraturan perundang-undangan bagi setiap warga negara dan penduduk atas barang jasa, dan/atau pelayanan administratif yang disediakan oleh penyelenggara pelayanan publik. Hal ini tidak jauh berbeda seperti yang tercantum dalam Keputusan Menteri Negara Pendayagunaan Aparatur Negara Nomor 63/KEP/M.PAN/7 /2003, yang memberikan pengertian:

"pelayanan publik yaitu segala kegiatan pelayanan yang dilaksanakan oleh penyelenggara pelayanan publik sebagai upaya pemenuhan kebutuhan penerima pelayanan maupun pelaksanaan ketentuan peraturan perundang undangan". 
Adapun penyelenggara pelayanan publik, merupakan setiap institusi penyelenggara negara, korporasi, lembaga independen yang dibentuk berdasarkan undang-undang untuk kegiatan pelayanan publik, dan badan hukum lain yang dibentuk semata-mata untuk kegiatan pelayanan publik. Sedangkan pelaksana pelayanan publik yang selanjutnya disebut Pelaksana adalah pejabat, pegawai, petugas, dan setiap orang yang bekerja didalam organisasi penyelenggara yang bertugas melaksanakan tindakan atau serangkaian tindakan pelayanan publik.

Berdasarkan fungsi pemerintah dalam melakukan pelayanan umum (publik) terdapat 3 (tiga) fungsi pelayanan, yaitu environmental service, development service, and protective service. Pelayanan yang diberikan oleh pemerintah juga dapat dibedakan berdasarkan siapa yang dapat menikmati atau memperoleh dampak dari suatu layanan, baik seseorang secara individu maupun kelompok atau kolektif. Untuk itu perlu disampaikan bahwa konsep barang layanan pada dasarnya terdiri dari jenis barang layanan privat (privategoods) dan barang layanan yang dinikmati secara kolektif (public goods).

\subsection{AZAS DAN PRINSIP-PRINSIP PELAYANAN PUBLIK}

\section{Azas-azas Pelayanan Publik}

Azas-azas Pelayanan Publik Agar pelayanan publik dapat berjalan secara efektif dan efisien dan memuaskan pelanggan/masyarakat, maka sesuai UU Pelayanan Publik Nomor 25 Tahun 2009, penyelenggaraan pelayanan publik berasaskan:

a. Kepentingan umum;

b. Kepastian hukum;

c. Kesamaan hak;

d. keseimbangan hak dan kewajiban; 
e. keprofesionalan;

f. partisipatif;

g. Persamaan perlakuan/tidak diskriminatif;

h. keterbukaan;

i. akuntabilitas;

j. fasilitas dan perlakuan khusus bagi kelompok rentan;

k. ketepatan waktu;dan

I. kecepatan, kemudahan, dan keterjangkauan.

Disamping azas-azas tersebut di atas, berikut ini azas azas pelayanan publik sesuai Keputusan Menteri PAN Tahun 2003 Nomor 63/KEP/M.PAN/2003, yakni:

a. Transparansi: Bersifat terbuka, mudah dan dapat diakses oleh semua pihak yang membutuhkan dan disediakan secara memadai serta mudah dimengerti.

b. Akuntabilitas: Dapat dipertanggungjawabkan sesuai dengan ketentuan peraturan perundang-undangan

c. Kondisional: Sesuai dengan kondisi dan kemampuan pemberi dan penerima pelayanan dengan tetap berpegang pada prinsip efisiensi dan efektifitas.

d. Partisipatif: Mendorong peran serta masyarakat dalam penyelenggaraan pelayanan publik dengan memperhatikan aspirasi, kebutuhan dan harapan masyarakat.

e. Kesamaan Hak: Tidak diskriminatif dalam arti tidak membedakan suku, ras, agama, golongan, gender dan status ekonomi.

f. Keseimbangan Hak dan Kewajiban: Keseimbangan Hak dan Kewajiban Pemberi dan penerima pelayanan publik harus memenuhi hak dan kewajiban masing-masing pihak. 


\section{Prinsip-prinsip Pelayanan Publik}

Dalam penyelenggaraan pelayanan publik perlu memperhatikan dan menerapkan prinsip-prinsip sebagai berikut:

a. Prinsip Kesederhanaan

Prosedur pelayanan publik tidak berbelit-belit, mudah dipahami dan mudah dilaksanakan.

b. Persyaratan teknis dan administratif pelayanan publik

Unit kerja/pejabat yang berwenang dan bertanggung jawab dalam

memberikan pelayanan dan penyelesaian keluhan / persoalan / sengketa dalam pelaksanaan pelayanan publik. Rincian biaya pelayanan publik dan tata cara pembayaran.

c. Prinsip Kepastian Waktu

Pelaksanaan pelayanan publik dapat diselesaikan dalam kurun waktu yang telah ditentukan.

d. Prinsip Akurasi

Produk pelayanan publik diterima dengan benar, tepat dan sah

e. Prinsip Keamanan

Proses dan produk pelayanan publik memberikan rasa aman dan kepastian hukum.

f. Prinsip Tanggung Jawab

Pimpinan penyelenggara pelayanan publik atau pejabat yang ditunjuk bertanggung jawab atas penyelenggaraan pelayanan dan penyelesaian keluhan/persoalan dalam pelaksanaan pelayanan publik.

g. Prinsip Kelengkapan Sarana dan Prasarana

Tersedianya sarana dan prasarana kerja, peralatan kerja, dan pendukung lainnya yang memadai, termasuk penyediaan sarana teknologi telekomunikasi dan informatika (telematika).

h. Prinsip Kemudahan Akses 
Tempat dan lokasi serta sarana pelayanan yang memadai, mudah dijangkau oleh masyarakat, dan dapat memanfaatkan teknologi telekomunikasi dan informatika.

i. Prinsip Kedisiplinan, Kesopanan dan Keramahan

Pelaksana pelayanan harus bersikap disiplin, sopan dan santun, ramah serta memberikan pelayanan dengan ikhlas.

j. Prinsip Kenyamanan

Lingkungan pelayanan harus tertib, teratur, disediakan ruang tunggu yang nyaman, bersih, rapi, lingkungan yang indah dan sehat serta dilengkapi dengan fasilitas pendukung pelayanan, seperti tempat parkir, toilet, tempat ibadah dan lain-lain.

\section{A. RUANG LINGKUP DAN JENIS PELAYANAN PUBLIK}

\section{Ruang Lingkup Pelayanan Publik}

Ruang lingkup pelayanan publik sesuai Undang-Undang Nomor 25 Tahun 2009 pasal 5 meliputi pelayanan barang publik dan jasa publik serta pelayanan administratif yang diatur dalam peraturan perundang-undangan, yakni meliputi pendidikan, pengajaran, pekerjaan dan usaha, tempat tinggal, komunikasi dan informasi, lingkungan hidup, kesehatan, jaminan sosial, energi, perbankan, perhubungan, sumber daya alam dan pariwisata

Pelayanan barang publik meliputi:

1) pengadaan dan penyaluran barang publikyang dilakukan oleh instansi pemerintah yang sebagian atau seluruh dananya bersumber dari anggaran pendapatan dan belanja negara dan/atau anggaran pendapatan dan belanja daerah;

2) pengadaan dan penyaluran barang publik yang dilakukan oleh suatu badan usaha yang modal pendiriannya sebagian atau seluruhnya bersumber dari kekayaan negara dan/atau kekayaan daerah yang dipisahkan. 
3) pengadaan dan penyaluran barang publik yang pembiayaannya tidak bersumber dari anggaran pendapatan dan belanja negara atau anggaran pendapatan dan belanja daerah atau badan usaha yang modal pendiriannya sebagian atau seluruhnya bersumber dari kekayaan negara dan/atau kekayaan daerah yang dipisahkan, tetapi ketersediaannya menjadi misi negara yang ditetapkan dalam peraturan perundangundangan

4) penyediaan jasa publik oleh instansi pemerintah yang sebagian atau seluruh dananya bersumber dari anggaran pendapatan dan belanja negara dan/atau anggaran pendapatan dan belanja daerah

5) penyediaan jasa publik oleh suatu badan usaha yang modal pendiriannya sebagian atau seluruhnya bersumber dari kekayaan negara dan/atau kekayaan daerah yang dipisahkan

6) penyediaan jasa publik yang pembiayaannya tidak bersumber dari anggaran pendapatan dan belanja negara atau anggaran pendapatan dan belanja daerah ataubadan usaha yang modal pendiriannya sebagian atau seluruhnya bersumber dari kekayaan negara dan/atau kekayaan daerah yang dipisahkan, tetapi ketersediaannya menjadi misi negara yang ditetapkan dalam peraturan perundang-undangan.

Pelayanan administratif merupakan pelayanan oleh penyelenggara yang menghasilkan berbagai bentuk dokumen resmi yang dibutuhkan oleh Masyarakat. Pelayanan administratif meliputi:

1) tindakan administrasi pemerintah yang diwajibkan dan diatur dalam peraturan perundang-undangan dalam rangka mewujudkan perlindungan pribadi, keluarga, kehormatan, martabat, dan harta benda warga negara. Contohnya adalah pelayanan kepada masyarakat untuk memiliki Surat Izin Mendirikan Bangunan (IMB), Surat Izin Usaha, Akte Kelahiran, Sertifikat Tanah, Surat Nikah/Cerai dan lain sebagainya. 
2) Tindakan administratif oleh instansi non pemerintah yang diwajibkan oleh negara dan diatur dalam peraturan perundang-undangan serta diterapkan berdasarkan perjanjian dengan penerima pelayanan. Contoh: a) urusan perbankan b) asuransi c) kesehatan d) keamanan e) pengelolaan kawasan industri, dan f) pengelolaan g) kegiatan sosial.

Tindakan administratif oleh instansi pemerintah sebagaimana dimaksud dalam point 1) diselenggarakan dalam bentuk pelayanan pemberian dokumen berupa "perizinan dan non perizinan" yang merupakan keputusan administrasi pemerintahan. Tindakan administratif pemerintah merupakan pelayanan pemberian dokumen oleh pemerintah, antara lain yang dimulai dari seseorang yang lahir memperoleh akta kelahiran hingga meninggal dan memperoleh akta kematian, termasuk segala hal ihwal yang diperlukan oleh penduduk dalam menjalani kehidupannya, seperti memperoleh izin mendirikan bangunan, izin usaha, sertifikat tanah,dan surat nikah.

Yang dimaksud dengan "keputusan administrasi pemerintahan" adalah keputusan tata usaha negara sebagaimana dimaksud dalam Undang-Undang Nomor 5 Tahun 1986 sebagaimana telah diubah dengan Undang-Undang Nomor 9 Tahun 2004 tentang Keputusan Tata Usaha Negara. Keputusan administrasi pemerintahan sebagaimana dimaksud merupakan keputusan. Penyelenggara yang bersifat penetapan. Keputusan yang bersifat penetapan misalnya Izin Mendirikan Bangunan (IMB), Surat Izin Usaha Perdagangan (SIUP), dan izin lain serta surat persetujuan. Keputusan non perizinan bentuknya berupa tanda, kartu atau bentuk keputusan lain sesuai ketentuan tentang tata naskah dinas, misalnya Kartu Tanda Penduduk, Nomor Pokok Wajib Pajak (NPWP), Bukti Kepemilikan Kendaraan Bermotor (BPKB), dan Sertifikat Tanah. 


\section{Jenis Pelayanan Publik}

3. Pelayanan dapat dibedakan menjadi tiga kelompok yaitu:

a) Core service

Core service adalah pelayanan yang ditawarkan kepada pelanggan yang merupakan produk utamanya. Untuk di Pemerintahan Provinsi DKI Jakarta misalnya menawarkan pelayanan terpadu satu pintu (PTSP) yang memberikan jaminan tenggat waktu jelas, Pasti, tepat, akurat, transparan dan tanpa pungutan.

b) Facilitating service

Facilitating service adalah fasilitas pelayanan tambahan kepada pelanggan, misalnya pelayanan "front office" pada hotel atau pelayanan "check in" pada transportasi udara. Facilitating service ini merupakan pelayanan tambahan tetapi sifatnya wajib. Contoh di DKI adalah pelayanan Transportasi Transjakarta yang menyediakan fasilitas lengkap di setiap halte, mulai dari kantin, tempat duduk yang nyaman, dan jaminan keamanan.

c) Supporting service

Supporting service merupakan pelayanan tambahan (pendukung) untuk meningkatkan nilai pelayanan atau untuk membedakan dengan pelayanan-pelayanan dari pihak "pesaingnya". Misalnya restoran pada suatu hotel. Supporting adalah pelayanan tambahan tetapi tidak wajib dan disediakan untuk meningkatkan daya saing. Janji pelayanan (service offering) pelayanan merupakan suatu proses yaitu interaksi antara pembeli (pelanggan) dan penjual (pemberi pelayanan). Contoh nyata di DKI Jakarta adalah adanya pelayanan dari pihak penyelenggara PTSP kepada masyarakat dengan dukungan informasi Real-Time, yang bisa dipantau oleh masyarakat tentang kepastian selesainya urusan pelayanan 


\section{BAB IV}

\section{PENUTUP}

\subsection{Kesimpulan}

NIB adalah Nomer Induk Berusaha, melalui satu pintu secara online . Pemerintah menerapkan progam satu pintu agar efektif dan efisien di dalam proses perizihan berusaha masyarakat Indonesia maupun warga Negara asing. OSS atau Online Single Submission dapat digunakan untuk mengurus perizinan usaha oleh : Bentuk Badan Usaha maupun Perorangan, Usaha Mikro, Kecil Menengah maupun besar, Usaha Perorangan/Badan usaha baik yang baru maupun yang sudah berdiri sebelum operasionalisasi OSS, Usaha dengan modal asing. Adapun manfaat OSS dalam NIB sebagai berikut : Mempermudah pengurusan berbagai perizinan berusaha baik persyaratan untuk melakukan usaha izin terkait lokasi, lingkungan, dan bangunan, izin usaha, maupun izin operasional untuk kegiatan operasional usaha di tingkat pusat ataupun daerah dengan mekanisme pemenuhan komitmen persyaratan izin, Memfasilitasi pelaku usaha untuk terhubung dengan semula stakeholder dan memperoleh izin secara aman, cepat dan real time, Memfasilitasi pelaku usaha dalam melakukan pelaporan dan pemecahan masalah perizinan dalam satu tempat, Memfasilitasi pelaku usaha untuk menyimpan data perizinan dalam satu identitas berusaha (NIB). NIB berlaku sebagai : (TDP) Tanda Daftar Perusahaan, Angka Pengenal Impor (API) jika pelaku melakukan kegiatan impor, Akses Kepabeanan jika pelaku usaha akan melakukan kegiatan ekspor atau impor, (SIUP) Surat Izin Usaha / (BKPM) Badan Koordinasi Penanaman Modal, Izin Domisili. 


\subsection{Saran}

1. Pemerintah seharusnya melakukan solialisasi terhadap Warga Negara Indonesia (WNI) maupun Warga Negara Asing (WNA).

2. Pemerintah seharusnya memberikan pemberitahuan untuk pendaftaran NIB di OSS.

3. masalah perizinan berada di sisi tata kelola dan bukan penyederhanaan prosedur.

Artinya, masalah perizinan berada di sisi tata kelola dan bukan penyederhanaan prosedur 


\section{DAFTAR PUSTAKA}

1. Waldo, Dwilight (1971) Administrasi Negara.

2. Chandler, dan Plano, dalam Keban (2004:3) Administrasi Negara.

3. Bailey (dalam Darwin,1997) Administrasi Negara.

4. Waluyo. 2007. Perpajakan Indonesia. Jakarta: Salemba Empat

5. Norman. (1991), 'Bentuk pelayanan prima yang mungkin menjadi harapan masyarakat di sebuah rumah sakit umum'

6. Undang-Undang Nomor 9 Tahun 2004 tentang Keputusan Tata Usaha Negara.

7. Undang-Undang Nomor 25 Tahun 2009 tentang pelayanan publik

8. Peraturan Pemerintah Nomor 24 Tahun 2018 tentang Pelayanan Perizinan Berusaha Terintegrasi Secara Elektronik

9. Negara Nomor 63/KEP/M.PAN/7 /2003, pelayanan publik.

10. Keputusan Menteri PAN Nomor 63/KEP/M.PAN/2003 Tahun 2003 tentang azazazaz pelayanan publik.

11. 
Artinya, masalah perizinan berada di sisi tata kelola dan bukan penyederhanaan prosedur. 